\title{
Medical students' attitudes towards mental stigmatization and its associated with own and familial psychosomatic disorders
}

\author{
Maxim Dmitriev ${ }^{1,2, *}$, Igor Reverchuk ${ }^{3}$, Marianna Glavatskikh $^{4}$, Artur Khejgetyan $^{2}$ and Ol'ga $^{\prime}$ \\ Kotsura \\ ${ }^{1}$ Don state Technical University, Rostov-on-Don, 344022, Russia \\ ${ }^{2}$ Rostov State Medical University, Rostov-on-Don, 344022, Russia \\ ${ }^{3}$ Immanuel Kant Baltic Federal University, Kaliningrad, 236016, Russia \\ ${ }^{4}$ Udmurt State University, Izhevsk 426034, Russia
}

\begin{abstract}
The problem of mental illness stigma is relevant in many countries. The position of the physicians is especially important, as they face patients with mental comorbid diseases. This study analyzes the attitudes of medical students towards mental stigmatization and reveals a relationship with the own and familial psychosomatic disorders common to the affective pathology. The first part of the study includes 229 respondents who answered 11 questions from the questionnaire «Social perceptions of mental health». The second part of the study involves 81 students who answered a questionnaire consisted of 18 questions on psychosomatic disorders among the respondents and their families. This study revealed a wide range of opinions on the of stigmatization among medical students. The indicator of negative attitude or stigmatization is diagnostic and reliable and was recorded in $24 \%$ of respondents. The data also obtained this opinion is frequent among student with gastrointestinal somatic symptoms. Lower level of stigmatization was found among students with affective disorders, as well as among students with a family history of sleep disorders, anxiety and a general level of somatic diseases. Medical students in their senior years have a wide range of opinions about psychiatry and mentally ill people. Personal and family experience of psychosomatic disorders is an important factor in reducing mental illness stigma.
\end{abstract}

\section{Introduction}

The mentally ill people stigma problem has existed for a long time in many countries of the world [1,2]. The range of factors that form prejudice is extremely wide: gender and ethnicity, religious traditions, profession, individual personality traits, educational level, presence and type of mental illness in family, own experience of psychosis and much more $[3,4,5,6,7,8]$.

One of these factors is ignorance of mental illness and modern methods of treatment among patients and society and fear caused by ingrained prejudices [9]. The consequence of

\footnotetext{
* Corresponding author: dmitriev.max@mail.ru
} 
this behavior is discrimination against mentally ill people [1]. They are often perceived as dangerous, weak, incompetent people [10]. This behavior worsens the social maladjustment of mentally ill people and interferes with the formation of remission [11,12].

The position of physicians is of particular importance. In recent decades, there has been an increase in borderline and affective mental illness. Most physicians are faced with patients with somatic and mental comorbidity. Currently, most patients with psychosomatic mental disorders receive care in primary health care $[13,14,15]$. However, patients prefer treatment from specialist medical care professionals [16]. Medicine residents are the first physicians who communicate with mentally ill people and can shape their attitudes towards illness and treatment strategies. Therefore, primary medical care physicians are responsible for identifying mental illness, primary diagnosis and prescribing initial therapy [17].

Mental illness stigma by therapists and primary medical care physicians is being explored in many countries. Violations of adequate professional interaction with specialized medical care centers were identified $[18,19]$. A biased approach interferes with quality care for the mentally ill people $[18,19]$. In many respects, this attitude among physicians is formed during their student years. The pattern of understanding, compassion and adequate response to mentally ill people that developed at this time can be critical in a future career. An adequate education and informational approach can play an important role in destigmatization [20, 21]. There is an opinion that changing the mental illness stigma should start at school and university [22].

A prejudiced attitude can be a manifestation own complexes based on children's and adolescent stereotypes about the exclusivity of oneself and own family and clan [3]. Ignorance of the variability of mental and psychosomatic disorders and the lack of projection of manifestations onto oneself or the family in the process of studying at a medical university may be associated with the transfer of psychiatry to the senior courses of the university program. Stereotypes about mandatory isolation, various kinds of administrative restrictions, an excessive emphasis on side effects in the drug treatment of psychosis interfere with the constructive, unbiased formation of the image of a mentally ill person.

However, researches conducted in Russia and other countries have shown that the passage of a psychiatry course by medical students does not significantly change their views on mental illness stigma $[6,23,24]$. An important role in destigmatization is played by direct contact with the patient during a sufficiently long clerkship and rotation of a psychiatric clinic $[25,26,27,28]$.

Special attention should be paid to data showing a significantly lower level of stigmatization among medical students who have personal or friendly involvement with mental illness, as well as those who are in contact with mentally ill people $[6,29,30]$.

The above circumstances motivated us to conduct our own research on mental illness stigma among medical students [31]. Most of the interviewers showed a negative, cautious and rejecting attitude towards mentally ill people, as well as a negative attitude towards psychiatry, both before and after studying psychiatry course [31].

Researches of the range of psychoemotional disorders, conducted at the same time among students of the same medical university, revealed a significant frequency of non-psychotic mental disorders, predominantly of the bipolar spectrum (hypomania, anxiety, depression) with comorbid psychosomatic manifestations, including eating disorders [32,33,34]. Most of the students with affective mental disorders did not realize that they had a mental disorder. Many had a family history of similar psychosomatic illnesses and addictive behavior. These researches prepared the basis for studying the relationship between mental illness stigma attitudes of students and the frequency of psychosomatic disorders in themselves and their families. The aim of this study was to analyze the attitudes of medical students towards mental stigmatization and their correlation with own and familial typical psychosomatic disorders characteristic of affective pathology. 


\section{Materials and methods}

This study consisted of 2 parts. The first part of the study involved 229 students ( 72 of them - male and 157 - female) 4-5 years of study at the Rostov State Medical University and 5 years of study at the Baltic Federal University. The average age of the subject was from 20 to 26 years. The survey was conducted before the course of psychiatry. All students signed a voluntary informed consent to take a survey and to process data. As a methodology, we used the questionnaire «Social Ideas of Mental Health» [35]. For questionnaire №1, 11 questions were selected reflecting such clusters of mental illness stigma as: «Control and rejection in relation to mentally ill people»-questions 1-6, «Attitudes towards psychiatry» - question 7, «Aggressive rejection»- questions 8-10, «Nonbiological concepts of mental illness»question 11. Sample questionnaire №1 is presented in table 1:

Table 1. Questionnaire attitudes towards mental illness, mentally ill people and psychiatry.

\begin{tabular}{|l|l|l|l|}
\hline \multirow{2}{*}{\multicolumn{1}{|c|}{ Questions }} & \multicolumn{2}{c|}{ Answer options } \\
\cline { 2 - 4 } & Yes & No & $\begin{array}{c}\text { I don't } \\
\text { know }\end{array}$ \\
\hline 1. Are mentally ill people dangerous? & & & \\
\hline $\begin{array}{l}\text { 2. Can't mentally ill people study in higher school } \\
\text { and university? }\end{array}$ & & & \\
\hline 3. Shouldn't the mentally ill people have children? & & & \\
\hline 4. Is it necessary to isolate mentally ill people? & & & \\
\hline $\begin{array}{l}\text { 5. Would you agree that a mentally ill person was } \\
\text { included in a group of my friend? }\end{array}$ & & & \\
\hline $\begin{array}{l}\text { 6. Would you agree that a mentally ill person was } \\
\text { your co-worker? }\end{array}$ & & & \\
\hline 7. Is psychiatry used to suppress dissidents? & & & \\
\hline 8. Do mentally ill people induce mostly distaste? & & & \\
\hline $\begin{array}{l}\text { 9. If someone you know becomes mental illness } \\
\text { will you stop communicating with him? }\end{array}$ & & & \\
\hline $\begin{array}{l}\text { 10. Is it a burden on society mentally ill people and } \\
\text { should they be destroyed? }\end{array}$ & & & \\
\hline 11. Is mental illness the result of weak character? & & & \\
\hline
\end{tabular}

The second part of the study was aimed at identifying the correlation of stigmatization in students with their own and family psychosomatic disorders, which are often found in young people with affective pathology. The second part of the study involved 81 students (17 of them - male and 64 - female) 5 years of study at the Rostov State Medical University and 5 years of study at the Baltic Federal University. The average age of the subject was from 21 to 25 years. All students signed a voluntary informed consent to take a survey and to process data. As a methodology, we used the questionnaire №2 consisting of 18 questions. They are typical disorders of somatic functions, instincts and other psychosomatic disorders found in medical students $[32,33]$. For analysis, the questions were grouped into the following clusters for the respondents themselves and their families: «Eating disorders» - questions 1, 2, 10, 15, 16, «Decreased libido»-question 3. «Somatic anxiety» - questions 4, 5, «Gastrointestinal somatic symptoms»-questions 6, 7, «Sleep disorders»-questions 8, 9, «Addictive behavior»-questions 11, 12, «Affective disorders»-questions 12, 13, «Suicidal thoughts»-question 17, «Menstrual irregularities»-question 18. Sample questionnaire №2 is presented in table 2 : 
Table 2. Questionnaire of psychosomatic disorders in respondents and families.

\begin{tabular}{|l|l|l|}
\hline \multicolumn{1}{|c|}{ Questions } & \multicolumn{1}{|c|}{ For me } & $\begin{array}{c}\text { For my family } \\
\text { (relation degree }\end{array}$ \\
\hline $\begin{array}{l}\text { 1. Tendency to overeat or binge eating } \\
\text { disorders }\end{array}$ & & \\
\hline 2. Tendency to overeat at night & & \\
\hline 3. Decreased libido or sexual activity & & \\
\hline 4. Unreasonable headaches & & \\
\hline $\begin{array}{l}\text { 5. Non-inflammatory or non-traumatic pain in } \\
\text { different parts of the body }\end{array}$ & & \\
\hline 6. Gastrointestinal symptoms: Constipation & & \\
\hline 7. Gastrointestinal symptoms: Diarrhea & & \\
\hline $\begin{array}{l}\text { 8. Sleep disorders: Difficulty falling asleep or } \\
\text { complete insomnia }\end{array}$ & & \\
\hline $\begin{array}{l}\text { 9. Sleep disorders: Waking in the middle of } \\
\text { the night or earlier in the morning }\end{array}$ & & \\
\hline 10. Tendency to polydipsia & & \\
\hline $\begin{array}{l}\text { 11. Tendency to abuse sleeping pills or } \\
\text { analgesics }\end{array}$ & & \\
\hline $\begin{array}{l}\text { 12. Tendency to abuse alcohol or narcotic } \\
\text { (toxic) substances }\end{array}$ & & \\
\hline $\begin{array}{l}\text { 13. Tendency to engage in dangerous or } \\
\text { aggressive behavior }\end{array}$ & & \\
\hline $\begin{array}{l}\text { 14. Tendency to periods of apathy (more than } \\
\text { 1 to 2 weeks) and inactivity }\end{array}$ & & \\
\hline $\begin{array}{l}\text { 15. Desire to lose weight despite normal or } \\
\text { even low weight }\end{array}$ & & \\
\hline 16. Periods of loss appetite & & \\
\hline 17. Suicidal thoughts, intentions, or actions & & \\
\hline $\begin{array}{l}\text { 18. FOR FEMALE ONLY } \\
\text { Menstrual irregularities not associated with } \\
\text { pregnancy and childbirth }\end{array}$ & & \\
\hline
\end{tabular}

\section{Results}

The results of the first part of the study are presented in table 3 .

Table 3. Outcomes of attitudes towards mental illness, mentally ill people and psychiatry.

\begin{tabular}{|c|c|c|c|}
\hline \multirow[b]{2}{*}{ Questions } & \multicolumn{3}{|c|}{ Answer options } \\
\hline & Yes & No & $\begin{array}{l}\text { I don't } \\
\text { know }\end{array}$ \\
\hline 1. Are mentally ill people dangerous? & $\begin{array}{c}89 \\
38.9 \%\end{array}$ & $\begin{array}{c}35 \\
15.3 \%\end{array}$ & $\begin{array}{c}105 \\
45.8 \%\end{array}$ \\
\hline $\begin{array}{l}\text { 2. Can't mentally ill people study in higher school } \\
\text { and university? }\end{array}$ & $\begin{array}{c}42 \\
18.3 \%\end{array}$ & $\begin{array}{c}101 \\
44.1 \%\end{array}$ & $\begin{array}{c}86 \\
37.6 \%\end{array}$ \\
\hline 3. Shouldn't the mentally ill people have children? & $\begin{array}{c}44 \\
19.2 \%\end{array}$ & $\begin{array}{c}117 \\
51.1 \%\end{array}$ & $\begin{array}{c}68 \\
29.7 \%\end{array}$ \\
\hline 4. Is it necessary to isolate mentally ill people? & $\begin{array}{c}46 \\
20.1 \%\end{array}$ & $\begin{array}{c}117 \\
51.1 \%\end{array}$ & $\begin{array}{c}66 \\
28.8 \%\end{array}$ \\
\hline $\begin{array}{l}\text { 5. Would you agree that a mentally ill person was } \\
\text { included in a group of my friend? }\end{array}$ & $\begin{array}{c}104 \\
45.4 \%\end{array}$ & $\begin{array}{c}59 \\
25.8 \%\end{array}$ & $\begin{array}{c}66 \\
28.8 \%\end{array}$ \\
\hline $\begin{array}{l}\text { 6. Would you agree that a mentally ill person was } \\
\text { your co-worker? }\end{array}$ & $\begin{array}{c}88 \\
38.4 \%\end{array}$ & $\begin{array}{c}99 \\
43.2 \%\end{array}$ & $\begin{array}{c}42 \\
18.4 \%\end{array}$ \\
\hline 7. Is psychiatry used to suppress dissidents? & 31 & 144 & 54 \\
\hline
\end{tabular}




\begin{tabular}{|l|c|c|c|}
\hline & $13.5 \%$ & $62.9 \%$ & $23.6 \%$ \\
\hline 8. Do mentally ill people induce mostly distaste? & 24 & 172 & 33 \\
& $10.5 \%$ & $75.1 \%$ & $14.4 \%$ \\
\hline 9. If someone you know becomes mental illness & 4 & 206 & 19 \\
will you stop communicating with him? & $1.7 \%$ & $90 \%$ & $8.3 \%$ \\
\hline 10. Is it a burden on society mentally ill people and & 2 & 219 & 8 \\
should they be destroyed? & $0.9 \%$ & $95.6 \%$ & $3.5 \%$ \\
\hline 11. Is mental illness the result of weak character? & 15 & 189 & 25 \\
& $6.6 \%$ & $82.5 \%$ & $10.9 \%$ \\
\hline
\end{tabular}

The reliability of the results of questionnaire №1 on the sum of the four scales is evidenced by the normal distribution of the final indicator of the questionnaire, which determines the negative attitude or stigmatization. The distribution normality was calculated using the Shapiro-Wilk test $(\mathrm{p}<0.005)$ and graphical indicators: asymmetry $(0.266)$ and kurtosis $(0.52)$. The data obtained allow us to conclude that the indicator is diagnostic. As a result of determining the statistical norm of the severity of the indicator (by calculating the mean (5.53) and the standard deviation (1.23)), it was revealed that the boundaries of the norm of the stigmatization indicator are from 4.9 to 6.2 . The average indicator is $112(51 \%)$ people (of which $19 \%$ are male and $81 \%$ of female), $58(26 \%)$ people have a low degree of severity (of which $25 \%$ are male and $75 \%$ of female), 54 (24\%) people have a high degree (of which $20 \%$ are male and $80 \%$ are female). So, the indicator of negative attitude or stigmatization is diagnostic and reliable and was recorded in $24 \%$ of respondents.

The results of the questionnaire survey on psychosomatic disorders among students and their families are presented in Table 4 . The number and frequency of positive statements are given.

Table 4. Results of the questionnaire on psychosomatic disorders in respondents and families.

\begin{tabular}{|c|c|c|}
\hline Questions & For me & $\begin{array}{c}\text { For my family } \\
\text { (relation degree }\end{array}$ \\
\hline $\begin{array}{l}\text { 1. Tendency to overeat or binge eating } \\
\text { disorders }\end{array}$ & $\begin{array}{c}20 \\
24.7 \%\end{array}$ & $\begin{array}{c}11 \\
13.6 \%\end{array}$ \\
\hline 2. Tendency to overeat at night & $\begin{array}{c}18 \\
22.2 \%\end{array}$ & $\begin{array}{c}6 \\
7.4 \%\end{array}$ \\
\hline 3. Decreased libido or sexual activity & $\begin{array}{c}11 \\
13.6 \%\end{array}$ & $\begin{array}{c}1 \\
1.2 \%\end{array}$ \\
\hline 4. Unreasonable headaches & $\begin{array}{c}28 \\
34.6 \%\end{array}$ & $\begin{array}{c}18 \\
22.2 \%\end{array}$ \\
\hline $\begin{array}{l}\text { 5. Non-inflammatory or non-traumatic pain in } \\
\text { different parts of the body }\end{array}$ & $\begin{array}{c}16 \\
19.8 \%\end{array}$ & $\begin{array}{c}9 \\
11.1 \%\end{array}$ \\
\hline 6. Gastrointestinal symptoms: Constipation & $\begin{array}{c}13 \\
16 \%\end{array}$ & $\begin{array}{c}6 \\
7.4 \%\end{array}$ \\
\hline 7. Gastrointestinal symptoms: Diarrhea & $\begin{array}{c}15 \\
18.5 \%\end{array}$ & $\begin{array}{c}8 \\
9.9 \%\end{array}$ \\
\hline $\begin{array}{l}\text { 8. Sleep disorders: Difficulty falling asleep or } \\
\text { complete insomnia }\end{array}$ & $\begin{array}{c}36 \\
44.4 \%\end{array}$ & $\begin{array}{c}11 \\
13.6 \% \\
\end{array}$ \\
\hline $\begin{array}{l}\text { 9. Sleep disorders: Waking in the middle of } \\
\text { the night or earlier in the morning }\end{array}$ & $\begin{array}{c}28 \\
34.6 \%\end{array}$ & $\begin{array}{c}9 \\
11.1 \%\end{array}$ \\
\hline 10. Tendency to polydipsia & $\begin{array}{c}8 \\
9.9 \%\end{array}$ & $\begin{array}{c}3 \\
3.7 \%\end{array}$ \\
\hline $\begin{array}{l}\text { 11. Tendency to abuse sleeping pills or } \\
\text { analgesics }\end{array}$ & $\begin{array}{c}3 \\
3.7 \%\end{array}$ & $\begin{array}{c}4 \\
4.9 \%\end{array}$ \\
\hline $\begin{array}{l}\text { 12. Tendency to abuse alcohol or narcotic } \\
\text { (toxic) substances }\end{array}$ & $\begin{array}{c}10 \\
12.3 \%\end{array}$ & $\begin{array}{c}5 \\
6.2 \%\end{array}$ \\
\hline $\begin{array}{l}\text { 13. Tendency to engage in dangerous or } \\
\text { aggressive behavior }\end{array}$ & $\begin{array}{c}7 \\
8.6 \%\end{array}$ & $\begin{array}{c}1 \\
1.2 \%\end{array}$ \\
\hline
\end{tabular}




\begin{tabular}{|l|c|c|}
\hline $\begin{array}{l}\text { 14. Tendency to periods of apathy (more than } \\
1 \text { to 2 weeks) and inactivity }\end{array}$ & 20 & 2 \\
\hline $\begin{array}{l}\text { 15. Desire to lose weight despite normal or } \\
\text { even low weight }\end{array}$ & $\begin{array}{c}24.7 \% \\
2.5 \%\end{array}$ \\
\hline 16. Periods of loss appetite & 28 & 1 \\
& $34.6 \%$ & 5 \\
\hline 17. Suicidal thoughts. intentions. or actions & 3 & $6.2 \%$ \\
\hline $\begin{array}{l}\text { 18. FOR FEMALE ONLY } \\
\text { Menstrual irregularities not associated with } \\
\text { pregnancy and childbirth }\end{array}$ & $3.7 \%$ & 0 \\
\hline
\end{tabular}

The next stage of our study was a statistical analysis of the comparison of the results presented in tables 3 and 4 . The influence of somatic indicators on the mental illness stigma was studied. Correlations were established between the studied indicators. Table 5 shows the results of correlation analysis using the nonparametric Spearman test.

Table 5. Reliable interrelationships of indicators of social ideas about mental health with somatic indicators of students and their families.

\begin{tabular}{|l|c|c|c|c|}
\hline \multicolumn{1}{|c|}{ Indicator name } & $\begin{array}{c}\text { Control and } \\
\text { rejection }\end{array}$ & $\begin{array}{c}\text { Attitudes } \\
\text { towards } \\
\text { psychiatry }\end{array}$ & $\begin{array}{c}\text { Aggressive } \\
\text { rejection }\end{array}$ & $\begin{array}{c}\text { Nonbiological } \\
\text { concepts }\end{array}$ \\
\hline $\begin{array}{l}\text { Gastrointestinal somatic } \\
\text { symptoms in respondents }\end{array}$ & $0.211^{*}$ & & \\
\hline $\begin{array}{l}\text { Affective disorders in } \\
\text { respondents }\end{array}$ & $-0.260^{*}$ & & $-0.232^{*}$ & $-0.294^{* *}$ \\
\hline Somatic anxiety in families & & & $-0.230^{*}$ \\
\hline $\begin{array}{l}\text { Sleeping disorders in } \\
\text { families }\end{array}$ & & & $-0.233^{*}$ \\
\hline $\begin{array}{l}\text { Final indicator of the } \\
\text { severity of somatic } \\
\text { disorders in families }\end{array}$ & & & \\
\hline Note: * significance level p is $0.05 * *$ significance level $p$ is 0.01 & \\
\hline
\end{tabular}

To establish individual indicators that affect the negative attitude of students, we carried out one-way variance (dichotomous indicators) using the Fisher test and regression analyzes with equal variances, compared indicators and their normal distribution. The higher these indicators, the less stigmatization. The analysis results are presented in table 6 .

Table 6. Influence of somatic indicators of students and their families on the final indicator of negative attitudes towards mentally ill people (the final indicator of the methodology).

\begin{tabular}{|l|c|}
\hline \multicolumn{1}{|c|}{ Indicators } & $\begin{array}{c}\text { Negative attitude towards mentally ill } \\
\text { people }(\mathbf{F})\end{array}$ \\
\hline Respondents headaches & $13.45^{* * *}$ \\
\hline Families headaches & $9.48^{* *}$ \\
\hline Families sleep disorders & $7.18^{* *}$ \\
\hline Note: ${ }^{* *}$ significance level p is $0,01^{* * *}$ significance level p is 0.001 \\
\hline
\end{tabular}

As a result of the analysis of all somatic indicators of students and their families, considered as predictors of negative attitudes (NA) towards mentally ill people (the final indicator of the questionnaire) of students, only one statistically significant "severity of somatic manifestations of families» was revealed. The results are presented in table 7. 
Table 7. Results of multiple regression analysis by forced inclusion of variables.

\begin{tabular}{|c|c|c|c|c|c|c|c|c|c|}
\hline \multirow{2}{*}{$\begin{array}{c}\text { Dependent } \\
\text { variable }\end{array}$} & \multirow{2}{*}{ Predictor } & \multicolumn{5}{|c|}{ Regression coefficients } & \multirow{2}{*}{$\mathbf{R}^{2}$} & \multirow{2}{*}{$\mathbf{F}$} & \multirow{2}{*}{ p } \\
\hline & & Constant & B & $\beta$ & $\mathbf{t}$ & $\mathbf{p}$ & & & \\
\hline NA & $\begin{array}{c}\text { Somatic } \\
\text { diseases of } \\
\text { families }\end{array}$ & 5.75 & 2.01 & 0.95 & 46.65 & 0.001 & 0.055 & 4.55 & 0.035 \\
\hline
\end{tabular}

The regression model $(\mathrm{F}=4.55 ; \mathrm{p}<0.01)$ and the regression coefficient of the predictor $(\mathrm{t}=46.65$ at $\mathrm{p}<0.001)$ are statistically significant. At the same time, $5.5 \%$ of the variance of the variable "negative attitude" of students is explained by the influence of this predictor. The linear regression equation has the following form: Negative ratio $=5.75-2.01 *$ (somatic manifestations of families).

At the second stage of the study, significant correlations were found between the attitude towards mentally ill people and students with their own somatic disorders: «Gastrointestinal somatic symptoms» $(\mathrm{r}=0.211 ; \mathrm{p}<0.05)$; «Affective disorders» $(\mathrm{r}=-0.260 ; \mathrm{p}<0.05)$ and indicators of families: «Somatic anxiety» $(\mathrm{r}=-0.232 ; \mathrm{p}<0.05$ with aggressive rejection and $\mathrm{r}=-0.294, \mathrm{p}<0.01 \mathrm{~s}$ nonbiological concepts $)$, «Sleep disorders» $(\mathrm{r}=0.230 ; \mathrm{p}<0.05)$, «final indicator» $(\mathrm{r}=-0.233 ; \mathrm{p}<0.05)$. The data also obtained this opinion is frequent among student with gastrointestinal somatic symptoms. Lower level of stigmatization was found among students with affective disorders, as well as among students whose families have sleep disorders, anxiety and a general level of somatic diseases.

Based on multiple regression analysis by the method of forced inclusion of variables, the results of which are shown in Table 7 , it can be concluded that more significant somatic symptoms in families reduce the negative attitude of students towards mentally ill people.

\section{Discussion}

This study found a wide range of opinions. A significant portion of interviewers (24\%), i.e. almost every fourth interviewed future physician has a negative attitude towards mentally ill people.

In the cluster «Control and rejection in relation to mentally ill people» $38 \%$ of the respondents believe that mentally ill people are dangerous. Approximately $18.5 \%$ believe that mentally ill people cannot study in higher school or university and cannot have children. One in five $(20 \%)$ considers it necessary to isolate mentally ill people. Every fourth $(25.8 \%)$ does not agree to friendship with mentally ill people. And a significant part of respondents $(43.2 \%)$ don't want co-worker to be a mentally ill person. In the «Attitudes toward psychiatry» cluster, $13.5 \%$ of respondents believe that psychiatry is used to suppress dissent. The «Aggressive rejection» cluster had the lowest percentage of mental illness stigma. However, one in ten $(10.5 \%)$ responds that they distaste mentally ill people. The cluster that has shown a positive trend in destigmatization is « Nonbiological concepts of mental illness». Only $6.6 \%$ of respondents believe that mental illness is the result of a weak character.

The results obtained can be associated with both ignorance in the field of psychiatry and reflect the existing social and family attitudes towards psychiatry and mentally ill people. An important mechanism for overcoming such mental illness stigma will be the receipt of a sufficient amount of specialized information, as well as personal contact with patients $[22,25,26,36]$. A significant problem here is the small amount of time for general study of psychiatry and practical work of students with patients in university programs in Russia, which is much less than in many European or Asian countries [31]. Therefore, clerkship is an essential and necessary component of medical courses. A meta-analysis [27] confirmed a good effect against mental illness stigma among medical students. 
The insignificant number of students with a non-biological understanding of mental illness can be explained by the good level of education in pathological physiology, pharmacology and neurology, which in Russia precede the course of psychiatry. Knowledge of these subjects prepares the student to understand the biological mechanisms of the formation of brain diseases.

The lack of personal contacts during training is partially compensated not only in the performance of professional duties, but also in family conditions. The second stage of the study confirmed the hypothesis of a link between the presence of psychosomatic disorders in respondents and their families with the level of mental illness stigma.

When analyzing the relationship between own psychosomatic disorders in respondents and their attitude towards mentally ill people, a direct correlation with the clusters «Gastrointestinal somatic symptoms» and an inverse correlation with the cluster «Affective disorders» were found. When studying this connection with psychosomatic problems in families, an inverse correlation with the clusters «Somatic anxiety» and «Sleep disorders» in families was revealed. Also, a predictor of negative attitudes towards mentally ill people, which are «Somatic disorders in families » was identified. It shows that the severity of somatic pathologies in relatives leads to a decrease in negative attitudes towards mentally ill people.

These results suggest that those young physicians who have experienced first-hand the suffering associated with mental illness are more humane towards other mentally ill people. Likewise, by empathizing with the suffering of their families, future physicians better understand that many behavioral and instinctive disorders in patients with psychosis are similar to those of their loved ones. The results obtained are comparable with the conclusions of other authors $[6,29,30]$.

\section{Conclusions}

This study revealed that a significant number of medical students in their senior years of study have a wide range of attitudes towards psychiatry and mentally ill people. Own and familial experience of psychosomatic disorders is an important factor in reducing mental illness stigma.

In preparing future physicians to prevent mental illness stigma and improve the quality of knowledge and skills in psychiatry, it is necessary to introduce several wishes. Changing the structure of training in the specialty of psychiatry with the obligatory sufficient contact between the student and the patient. Active realization of the principles of psychiatry rotation and communication training implementation. Analyze the psychiatric myths and mental illness stigmas existing in the public consciousness in order to develop a rational medical approach. To pay more attention to the role of medical psychology for the awareness of medical students of their own emotions, phobias and beliefs, which can be useful for transforming existing mental illness stigma and increasing their competence and self-esteem.

\section{References}

1. P.W. Corrigan, A.C. Watson, World psychiatry: official journal of the World Psychiatric Association (WPA) 1(1), 16-20 (2002)

2. G. Schomerus, C. Schwahn, A. Holzinger, P.W. Corrigan, H.J. Grabe, M.G. Carta, M.C. Angermeyer, Acta psychiatrica Scandinavica 125(6), 440-452 (2012) https://doi.org/10.1111/j.1600-0447.2012.01826.x

3. I.B. Bovina, B.G. Bovin, Psihologiya i pravo 4, 1-10 (2013)

4. L.Y. Serebrijskaya, ZHurnal nevrologii i psihiatrii 105(3), 47-54 (2005) 
5. A.E. Melik-Pashayan, E.V. Mironova, Psihiatriya i psihofarmakoterapiya 15(3), 68-72 (2013)

6. A. Korszun, S. Dinos, K. Ahmed, K. Bhui, Academic psychiatry: the journal of the American Association of Directors of Psychiatric Residency Training and the Association for Academic Psychiatry 36(3), 197-204 (2012) https://doi.org/10.1176/appi.ap.10110159

7. I.V. Reverchuk, Yu.Yu. Khudyakova, Zhurnal nevrologii i psikhiatrii imeni S.S. Korsakova 116(10), 24-27 (2016) https://doi.org/10.17116/jnevro201611610124-27

8. U. Von Lersner, J. Gerb, S. Hizli, D. Waldhuber, et al, Frontiers in psychiatry 10, 46 (2019) https://doi.org/10.3389/fpsyt.2019.00046

9. A. Dyduch, A. Grzywa, Polski merkuriusz lekarski: organ Polskiego Towarzystwa Lekarskiego 26(153), 263-267 (2009)

10. K. Furczyk, E. Górniak, R. Skowronek, M. Gajda, K. Krysta, I. Krupka-Matuszczyk, Psychiatria Danubina 23(1), 46-49 (2011)

11. G.P. Kostyuk, A.V. Masyakin, L.A. Burygina, I.V. Reverchuk, Neuroscience and Behavioral Physiology 50, 45-50 (2020) https://doi.org/10.1007/s11055-019-00867-0

12. G. Schomerus, S. Van der Auwera, H. Matschinger, S.E. Baumeister, M.C. Angermeyer, Acta psychiatrica Scandinavica 132(5), 357-364 (2015) https://doi.org/10.1111/acps.12401

13. M. Copty, D.L. Whitford, Irish journal of psychological medicine 22(3), 83-86 (2005) https://doi.org/10.1017/S079096670000906X

14. R. Kessler, Journal of the American Board of Family Medicine: JABFM 25(2), 255-259 (2012) https://doi.org/10.3122/jabfm.2012.02.100125

15. E. van Rijswijk, M. Borghuis, E. van de Lisdonk, F. Zitman, C. van Weel, International journal of clinical pharmacology and therapeutics 45(1), 23-29 (2007) https://doi.org/10.5414/cpp45023

16. K. Harmon, V.J. Carr, T.J. Lewin, Journal of advanced nursing 32(6), 1459-1466 (2000) https://doi.org/10.1046/j.1365-2648.2000.01616.x

17. V.N. Krasnov, T.V. Dovzhenko, A.E. Bobrov, E.G. Starostina, ZHurnal "Social'naya i klinicheskaya psihiatriya" 23(4), 5-13 (2013)

18. A. Vistorte, W.S. Ribeiro, D. Jaen, M.R. Jorge, S. Evans-Lacko, J.J. Mari, International journal of psychiatry in medicine 53(4), 317-338 (2018) https://doi.org/10.1177/0091217418778620

19. T.P. Lam, K.F. Lam, E.W. Lam, Y.S. Ku, Asia-Pacific psychiatry: official journal of the Pacific Rim College of Psychiatrists 5(1), E19-E28 (2013) https://doi.org/10.1111/j.1758-5872.2012.00208.x

20. G. Wolff, S. Pathare, T. Craig, J. Leff, The British journal of psychiatry: the journal of mental science 168(4), 441-447 (1996) https://doi.org/10.1192/bjp.168.4.441

21. F. Martínez-Zambrano, E. García-Morales, M. García-Franco, et al, World journal of psychiatry 3(2), 18-24 (2013) https://doi.org/10.5498/wjp.v3.i2.18

22. R. Milin, S. Kutcher, S.P. Lewis, S. Walker, Y. Wei, N. Ferrill, M.A. Armstrong, Journal of the American Academy of Child and Adolescent Psychiatry 55(5), 383-391 (2016) https://doi.org/10.1016/j.jaac.2016.02.018

23. V.A. Ruzhenkov, U.S. Moskvitina, Sibirskij vestnik psihiatrii i narkologii 3, 42-45 (2010) 
24. N.K. Rzhevskaya, V.A. Ruzhenkov, Nauchnye vedomosti Belgorodskogo gosudarstvennogo universiteta. Seriya: Medicina. Farmaciya 10(129), 5-11 (2012)

25. Z. Lyons, A. Janca, BMC medical education 15, 34 (2015) https://doi.org/10.1186/s12909-015-0307-4

26. Y. Shen, H. Dong, X. Fan, Z. Zhang, L. Li, H. Lv, Z. Xue, X. Guo, International journal of psychiatry in medicine 47(3), 241-254 (2014) https://doi.org/10.2190/PM.47.3.e

27. E. Petkari, A.I. Masedo Gutiérrez, M. Xavier, B. Moreno Küstner, Medical education 52(7), 694-704 (2018) https://doi.org/10.1111/medu.13548

28. C. De Witt, I. Smit, E. Jordaan, L. Koen, D. Niehaus, U. Botha, BMC medical education 19(1), 114 (2019) https://doi.org/10.1186/s12909-019-1543-9

29. M. Meyers, J. Geldmacher, S. Mattausch, et al, Der Nervenarzt 88(11), 1266-1272 https://doi.org/10.1007/s00115-016-0189-7

30. H.C. Eksteen, P.J. Becker, G. Lippi, The International journal of social psychiatry 63(8), 782-791 (2017) https://doi.org/10.1177/0020764017735865

31. M.N. Dmitriev, A.N. Sannikox, Glavnyj vrach Yuga Rossii 5(69), 71-75 (2019)

32. A.F. Hejgetyan, T.V. Dunajceva, E.M. Macyuk, E.V. Obrazcova, Somatonevrologia materialy mezdhunarodnoj nauchno-prakticheskoj konferencii studentov $i$ molodyh uchenyh, 84-91 (2019)

33. T.V. Dunajceva, E.M. Macyuk, E.V. Obrazcova, A.F. Hejgetyan, I.S. Ismailov, Somatonevrologia - materialy mezdhunarodnoj nauchno-prakticheskoj konferencii studentov i molodyh uchenyh, 21-32 (2019)

34. E.V. Obrazcova, E.M. Macyuk, T.V. Dunajceva, A.N. Sannikox, M.N. Dmitriev, Sovremennye aspekty formirovaniya ZOZH u molodogo pokoleniya - Sbornik materialov vserossijskoj nauchno-prakticheskoj konferencii studentov $i$ molodyh uchenyh, 74-77(2019)

35. L.Y. Serebrijskaya, V.S. YAstrebov, S.N. Enikolopov, Zhurnal nevrologii i psikhiatrii imeni S.S. Korsakova 102(9), 59-68 (2002)

36. N. Simon, H. Verdoux, L'Encephale 44(4), 329-336 (2018) https://doi.org/10.1016/j.encep.2017.05.003 